\title{
Rooting systems of western and southern African Faidherbia albida (Del.) A. Chev. (syn. Acacia albida Del.) - a comparative analysis with biogeographic implications ${ }^{1}$
}

\author{
R. J. VANDENBELDT \\ ICRISAT Sahelian Center, B.P. 12404, Niamey, Niger
}

Key words: Faidherbia albida, agroforestry, ecotypes, rooting systems, West Africa, provenance trials

\begin{abstract}
Faidherbia albida is a well-known and widespread agroforestry species of the Sudano-Sahelian zone of West Africa. Recent collection and testing efforts have included attempts to introduce seed origins from eastern and southern Africa into the Sahel. These have generally met with failure. Despite superior early growth, mortality is severe by the first or second year. Trials conducted at the ICRISAT Sahelian Center in Niger have demonstrated that this is probably due to differences in rooting patterns between southern and western Africa origins. A separation of the species into two ecotypes, i.e., upland (western Africa) and riparian (eastern, southern and southwestern Africa) is proposed. Based on this argument, the Sudan/Ethiopia region is identified as a possible center of origin for the species.
\end{abstract}

Resumé. Faidherbia albida est une espèce agroforestière bien connue et répandue dans la zone soudano-sahélienne de l'Afrique de l'ouest. Des prospections et évaluations récentes ont visé, entre autres, à introduire au Sahel des semences provenant d'Afrique orientale et australe. Ces tentatives ont généralement échoué. Malgré une excellet croissance juvénile, le taux de mortalité des introductions a été élevé durant les deux premières années. Des essais conduits au Centre sahélien de l'ICRISAT, au Niger, ont montré que cette mortalité pourrait être associée à un profil d'enracinement distinct entre les arbres d'Afrique occidentale et ceux d'Afrique australe. Une division de l'espèce en deux écotypes - celui des zones de plateaux (Afrique de l'ouest) et celui des zones ripicoles (Afrique de l'est, du sud et du sud-ouest) est proposée. La région Soudan/Ethiopie pourrait alors être considérée comme le centre d'origine de cette espéce.

\section{Introduction}

Faidherbia albida is an important component of parkland agroforestry systems in sub-Saharan Africa. In the Sudano-Sahelian zone, variable numbers of trees are retained by farmers in cropped fields, usually to the benefit of crops growing underneath. Documentation of this 'albida effect' is well known to readers of agroforestry literature [3, 5]. 'Islands of fertility', around mature albida trees are characterized by increased levels of soil organic matter, cations, and phosphorus.

F. albida occurs naturally over much of the African continent. From the

1 Submitted as ICRISAT Journal Article \# JA-1107. 
Gambia and Senegal, its range extends east to Egypt, Sudan, and Ethiopia and then along the eastern coast into southern Africa. A significant natural population exists in Angola and Namibia. In addition, small, possibly residual populations exist in Israel and Lebanon [11]. There are reports of its occurrence in Libya, Cyprus and Cape Verde, although these are probably recent introductions [13].

F. albida in western Africa is invariably associated with man and his agricultural and pastoral activities. In this region, F. albida occurs on a wide range of soils and climatic conditions. Although often associated with depressions and river valleys, it is also common on sites with deep water tables (>30 m). In contrast to this, the species is riparian in eastern and southern Africa, occurring notably along the Nile, Zambezi and Limpopo river drainage systems and in other areas with shallow water tables. It is rarely integrated into cropping or pastoral systems in these regions.

Two races of the species were recognized by Brenan [2]; race A, with small, glabrous leaflets occurring in eastern Africa, and Race B, with large, pubescent leaflets occurring in southern Africa. Both races occur, with numerous intermediate types, in western Africa.

There has been much effort in the past 15 years to introduce and/or reintroduce $F$. albida in farmer's fields, especially in Sahelian Africa. Introduction of $F$. albida from southern Africa into the Sahel was expected to be of benefit to these efforts [6]. In two examples, height growth of plants of southern Africa seed origins was greater than for Sahelian seed origins, sometimes by a factor of two, during the first few rainy seasons. However, they suffered heavy mortality after one or two years (A. Issa, Institut national de recherches agronomiques du Niger, Niamey, Niger; E.G. Bonkoungou, Director, Institut de recherche en biologie et écologie tropicale, Ouagadougou, Burkina Faso, personal communications, 1989).

This study was undertaken to better understand differences in early growth rates and survival of southern and Sahelian seed origins of $F$. albida.

\section{Materials and methods}

The experiment was located at the ICRISAT Sahelian Center (ISC), $45 \mathrm{~km}$ south of Niamey, Niger at $13^{\circ} \mathrm{N} 2^{\circ} \mathrm{E}$. Niamey receives an average of 562 $\mathrm{mm}$ of rainfall (standard deviation $=134 \mathrm{~mm}$ ), most of which falls during June-September. Average potential evapotranspiration during the dry months of October-May is $1820 \mathrm{~mm}$ [10]. At ISC, rainfall was $700 \mathrm{~mm}$ in 1988 and $623 \mathrm{~mm}$ in 1989.

The soil was a Labucheri series of the Psammentic Paleustalf (sandy, siliceous, isohyperthermic) family. The Labucheri series is characterized by a high sand fraction $(>90 \%$ ), moderate acidity, poor water retention $(<10 \%)$ and low nutrient status. The soil has a clear depth of $3-4 \mathrm{~m}$, overlying a gravelly lateritic layer [12]. Depth to water table is about $20 \mathrm{~m}$. 
These traits make the soil ideal for root growth studies, because roots can grow unimpeded and are excavable to depths of 4-5 m.

In normal rainfall years, the soil retains sufficient moisture $(8-10 \%)$ at depths exceeding $2 \mathrm{~m}$, well past the end of the rainy season (Fig. 1). This allows for seedling root development into the long dry season. By the end of the dry season, the profile is again depleted of soil moisture $(3-4 \%)$. In such an environment, tree species with aggressive taproots that can grow past this drying zone would have an advantage.

Seed of 32 origins of $F$. albida were obtained from various international and national research institutes in west and southern Africa (Table 1). The 9 seed origins obtained from eastern and southern Africa covered the area from Kenya to the Limpopo River (Republic of South Africa), a N-S distance of nearly $3000 \mathrm{~km}$. A similar $3000 \mathrm{~km} \mathrm{E}-\mathrm{W}$ distance was represented by the west Africa origins, which ranged from eastern Chad to western Burkina Faso.

Seed was hand-scarified by nicking the edge, and sown three to a pot (100 pots per seed lot). Three-month old seedlings were outplanted on

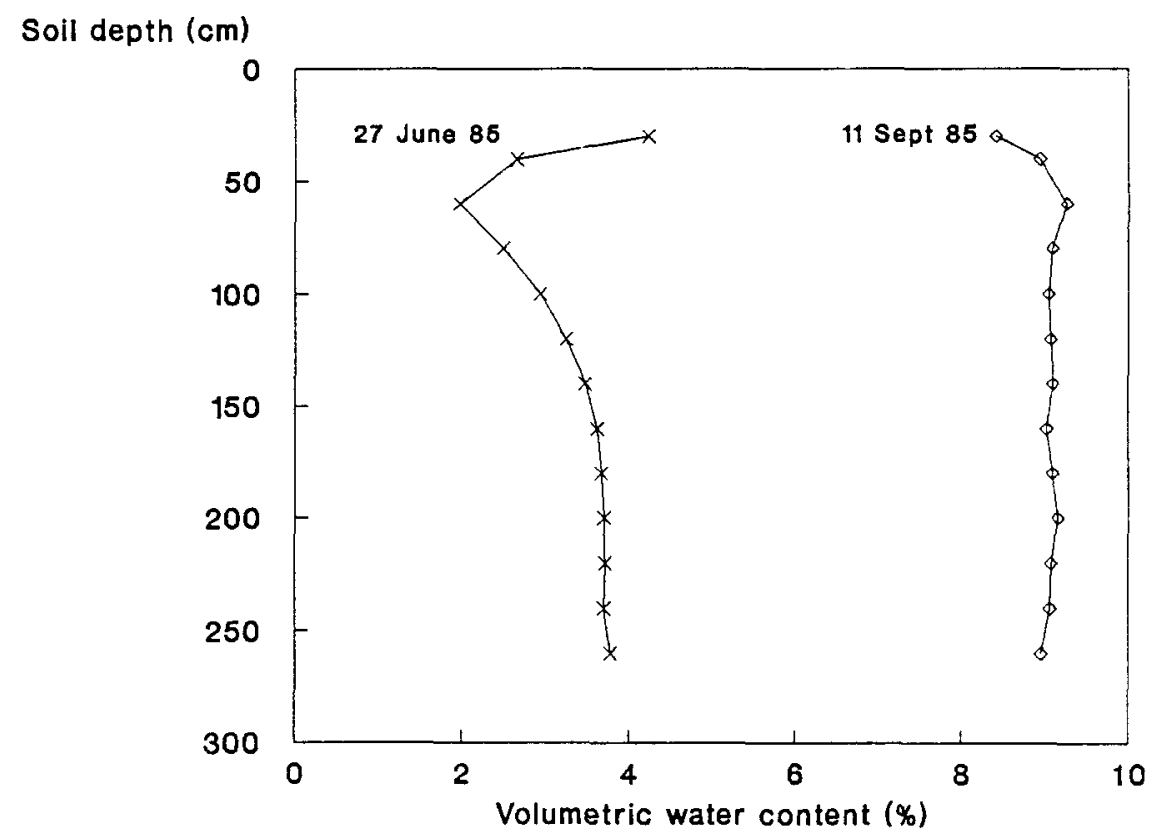

Fig. I. Moisture profiles of a Labucheri series soil at the beginning and end of a normal rainfall growing season, ISC, Sadore, Niger. $\mathrm{CV}=0.85 \%$. (source: M. C. Klaij, ICRISAT Sahelian Center). 
Table 1. Information of seed origins of Faidherbia albida included in study. 1SC, Sadore, 1988-1990.

\begin{tabular}{llllll}
\hline Code & Inst. & Prov. No. & Location & Year & No. Reps \\
\hline
\end{tabular}

\section{Southern/Eastern Africa}

$\begin{array}{lll}\text { Z-1 } & \text { ZFRI }^{a} & 17330 \\ Z-2 & \text { ZFRI } & 17331 \\ \text { Z-3 } & \text { ZFRI } & 17332 \\ \text { Z-4 } & \text { ZFRI } & 17333 \\ \text { Z-5 } & \text { ZFRI } & 17334 \\ \text { Z-6 } & \text { ZFRI } & 13846 \\ \text { Z-7 } & \text { ZFRI } & 13995 \\ \text { Z-8 } & \text { ZFRI } & 13996 \\ \text { Z-9 } & \text { ZFRI } & 13306\end{array}$

$\begin{array}{lll}\text { Mana, Zimbabwe } & . & 4 \\ \text { Chipinda, Zimbabwe } & . & 4 \\ \text { Hwange, Zimbabwe } & . & 4 \\ \text { S/E Lowveld, Zimbabwe } & \ldots & 4 \\ \text { N. Matabeleland, Zimbabwe } & \ldots & 4 \\ \text { Malawi (bulked, 3 origins) } & \ldots & 4 \\ \text { Messina, Rep. South Afr. } & . & 3 \\ \text { Katima Mulilo, S. Afr. } & \ldots & 3 \\ \text { Lodwar, Kenya } & \ldots & 3\end{array}$

Western Africa

\begin{tabular}{|c|c|c|c|c|}
\hline I-1 & IBPGR $^{b}$ & TCD-041 & Am Sak (Batha), Chad & 1987 \\
\hline $\mathrm{I}-2$ & IBPGR & MLI-003 & Mopti, Mali & 1987 \\
\hline I-3 & IBPGR & TCD-058 & Am Zoer, Ouaddai, Chad & 1987 \\
\hline $\mathrm{C}-1$ & $\mathrm{CNSF}^{\circ}$ & 178 & Kongoussi, B.F. & 1984 \\
\hline $\mathrm{C}-2$ & CNSF & 183 & Tougan, B.F. & 1984 \\
\hline$C-3$ & CNSF & 250 & Woursom, Ouahigay, B.F. & 1984 \\
\hline $\mathrm{C}-4$ & CNSF & 241 & Mesrido, Yako, B.F. & 1984 \\
\hline $\mathrm{C}-5$ & CNSF & 774 & Gomblora, Gaoua, B.F. & 1987 \\
\hline$C-6$ & CNSF & 772 & Soubaka, B.F. & 1987 \\
\hline $\mathrm{C}-7$ & CNSF & 769 & Kossara, Poura, B.F. & 1987 \\
\hline C-8 & CNSF & 738 & Zorkoum Kaya, B.F. & 1987 \\
\hline $\mathrm{C}-9$ & CNSF & 577 & Tcheriba, Dedougou, B.F. & 1986 \\
\hline $\mathrm{C}-10$ & CNSF & 371 & Sion, Safane, B.F. & 1985 \\
\hline $\mathrm{C}-11$ & CNSF & 332 & Diou, Leo, B.F. & 1985 \\
\hline $\mathrm{C}-12$ & CNSF & 17 & Dassouri, B.F. & 1984 \\
\hline$C-13$ & CNSF & 316 & Binde, Manga, B.F. & 1985 \\
\hline C-14 & CNSF & 767 & Markoye, B.F. & 1987 \\
\hline $\mathrm{N}-1$ & INRAN $^{d}$ & .. & Bakim Birji, Niger & 1987 \\
\hline $\mathrm{N}-2$ & INRAN & . . & Bouza, Niger & 1987 \\
\hline$N-3$ & INRAN & . & Dakoro, Niger & 1987 \\
\hline$N-4$ & INRAN & $\ldots$ & Madarounfa, Niger & 1987 \\
\hline$N-5$ & INRAN & . & Matimeye, Niger & 1987 \\
\hline$N-5$ & $\mathrm{ISC}^{\mathrm{e}}$ & $\ldots$ & Sadore, Niger & 1988 \\
\hline
\end{tabular}

a Zimbabwe Forest Research Institute, Harare, Zimbabwe.

b International Board for Plant Genetic Resources, Niamey, Niger.

c Center national de semences forestiéres, Ouagadougou, Burkina Faso.

d Institut national de recherches agronomiques du Niger, Niamey.

e ICRISAT Sahelian Center, Niamey, Niger. 
August 15, 1988, irrigated with 21 of water, fertilized with $30 \mathrm{~g}$ of 15-1515 , and given a $3.5 \mathrm{~g}$ dose of Carbofuran ( $3 \%$ a.i.), all mixed thoroughly with the backfill. Seedlings were weeded twice during the 1988 rainy season and once during the 1989 season.

Germination of several seedlots was very poor. As a result, not all origins could be replicated equally in the trial. Because of this, a randomized incomplete block design was used, consisting of 18 core entries present in all 4 replications, with the remaining 13 seed lots assigned randomly to replications depending on the number of available seedlings. This made an average of 26 plots per replication (Table 1). Plots consisted of 10 trees planted in single rows, unbordered, spaced at $2 \mathrm{~m}$ within plot rows and $3 \mathrm{~m}$ between plots. A border separating the replications and another surrounding the entire trial were established using the Sadore local seed origin.

Live height (dead tops were not measured), basal diameter and survival were recorded monthly for all trees during the first four months and thereafter at $0.5,1.0$ and 1.5 years. Between eight and nine months of age, five plants each of a border row (Sadore, Niger) and a southern origin (Messina, RSA) occurring side by side in the experiment were excavated to a depth of $4 \mathrm{~m}$ to compare root development. Roots greater than $2 \mathrm{~mm}$ in diameter were traced and measured. Above- and below-ground biomass and distribution of roots down the soil profile were recorded.

Data were analyzed using the SAS General Linear Modeling procedure for personal computers [9]. Plot averages, based on the number of surviving trees at the time of data collection, were used. Only comparisons between geographic localities - western (or Sahelian) versus southern and eastern Africa - are reported.

\section{Results}

Early above-ground growth of seedlings of the southern origins exceeded that of Sahelian origins. Four months after outplanting, plants of southern entries had $24 \%$ greater average diameter and nearly double the average height than the Sahelian entries (Table 2). Residual soil moisture was adequate during this period. As a result, there was little mortality among any of the outplanted seedlings. However, as soil water became limiting in February and March, plants of southern and eastern seed origins defoliated slowly, and their growth rate slowed. Onset of defoliation in Sahelian entries occurred in early March, about a month after the southern entries.

By the end of the first dry season, the southern plots had over $50 \%$ mortality. This reached nearly $62 \%$ by the end of the first year (Fig. 3) and exceeded $90 \%$ by 1.5 years of age for southern Africa entries. By 1.9 years, all plants from southern and eastern African origins died. Survival of Sahelian lines, on the other hand, exceeded $95 \%$ for all entries. 
Table 2. Height, diameter, and survival of 31 Faidherbia albida origins planted at ISC, Sadore, Niger, 1988 (4 months).

\begin{tabular}{lllll}
\hline No. & $\begin{array}{l}\text { Diameter } \\
(\mathrm{cm})\end{array}$ & $\begin{array}{l}\text { Height } \\
(\mathrm{m})\end{array}$ & $\begin{array}{l}\text { Survival } \\
\text { Original }\end{array}$ & Transformed $^{\mathrm{a}}$ \\
\hline
\end{tabular}

Southern and eastern Africa

$\begin{array}{rrrrr}\text { Z-1 } & 1.3 & 1.2 & 100 & 10.0 \\ \text { Z-2 } & 1.4 & 1.4 & 100 & 10.0 \\ \text { Z-3 } & 1.2 & 1.1 & 100 & 10.0 \\ \text { Z-4 } & 1.4 & 1.2 & 100 & 10.0 \\ \text { Z-5 } & 1.1 & 1.1 & 100 & 10.0 \\ \text { Z-6 } & 1.4 & 1.3 & 100 & 10.0 \\ \text { Z-7 } & 1.0 & 1.0 & 100 & 10.0 \\ \text { Z-8 } & 0.8 & 0.8 & 100 & 10.0 \\ \text { Z-9 } & 0.8 & 0.7 & 97 & 9.8\end{array}$

\section{Western Africa}

\begin{tabular}{|c|c|c|c|c|}
\hline I-1 & 0.8 & 0.6 & 100 & 10.0 \\
\hline $\mathrm{I}-2$ & 1.1 & 0.7 & 100 & 10.0 \\
\hline I-3 & 0.9 & 0.6 & 100 & 10.0 \\
\hline C-1 & 0.9 & 0.6 & 100 & 10.0 \\
\hline$C-2$ & 1.0 & 0.7 & 100 & 10.0 \\
\hline C-3 & 0.8 & 0.6 & 100 & 10.0 \\
\hline C-4 & 0.8 & 0.6 & 100 & 10.0 \\
\hline$C-5$ & 1.8 & 0.9 & 97 & 9.8 \\
\hline$C-6$ & 1.0 & 0.8 & 100 & 10.0 \\
\hline C-7 & 0.8 & 0.6 & 100 & 10.0 \\
\hline C-8 & 0.7 & 0.6 & 100 & 10.0 \\
\hline$C-10$ & 0.8 & 0.5 & 95 & 9.7 \\
\hline$C-11$ & 0.7 & 0.5 & 100 & 10.0 \\
\hline$C-12$ & 0.9 & 0.5 & 100 & 10.0 \\
\hline C-13 & 0.6 & 0.4 & 100 & 10.0 \\
\hline C-14 & 0.9 & 0.6 & 100 & 10.0 \\
\hline $\mathrm{N}-1$ & 0.9 & 0.7 & 100 & 10.0 \\
\hline $\mathrm{N}-2$ & 1.0 & 0.7 & 100 & 10.0 \\
\hline N-3 & 1.0 & 0.7 & 100 & 10.0 \\
\hline $\mathrm{N}-4$ & 1.0 & 0.8 & 100 & 10.0 \\
\hline $\mathrm{N}-5$ & 1.0 & 0.7 & 100 & 10.0 \\
\hline $\mathrm{N}-6$ & 1.0 & 0.8 & 100 & 10.0 \\
\hline Mean & 1.0 & 0.8 & 99.7 & 9.98 \\
\hline $\mathrm{SE}_{\mathrm{x}}$ & 0.3 & 0.1 & - & $0.06^{\mathrm{a}}$ \\
\hline $\mathrm{CV}$ & 35 & 21 & - & 0.81 \\
\hline South & 1.2 & 1.1 & 99.7 & 9.98 \\
\hline West & 0.9 & 0.7 & 99.8 & 9.99 \\
\hline $\mathrm{SE}_{\mathrm{x}}$ & 0.3 & 0.1 & - & 0.06 \\
\hline $\mathrm{CV}$ & 36 & 24 & - & 0.87 \\
\hline
\end{tabular}

a Square root transformation. Only SE's for transformed values are used for mean comparison. 
This mortality is reflected in the comparison of basal diameter and height growth at 1.0 and 1.5 years (Fig. 2). Among the southern African lines, the largest trees died first, resulting in a general decline in both average plot heights and basal diameters. All plants of the southern entries suffered top dieback.

Above-ground growth parameters of the excavated plants were similar to the averages of entries from their respective geographic regions (Table 3). Average height $(n=5)$ of the southern entry (Messina, RSA) was greater than that of the Sahelian entry (Sadore, Niger), however, basal diameter

a)

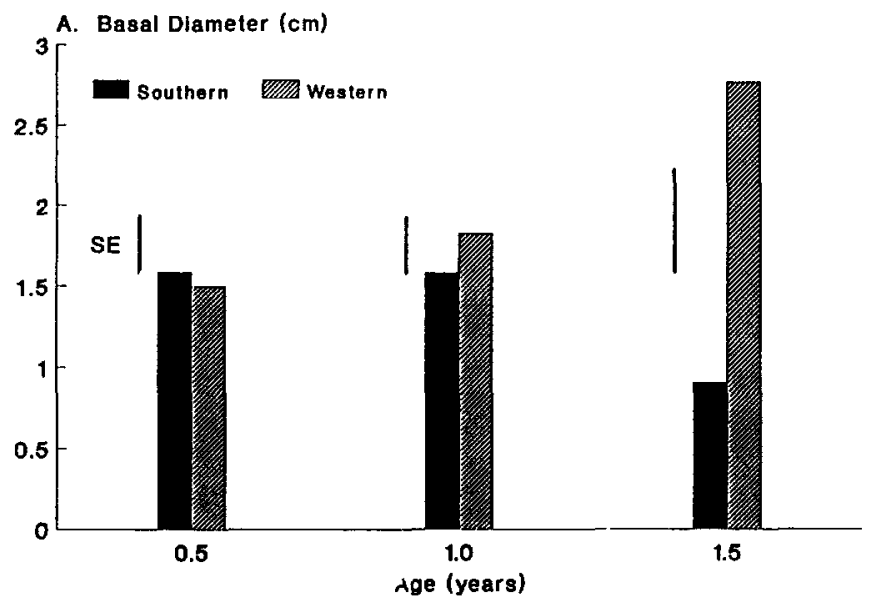

b)

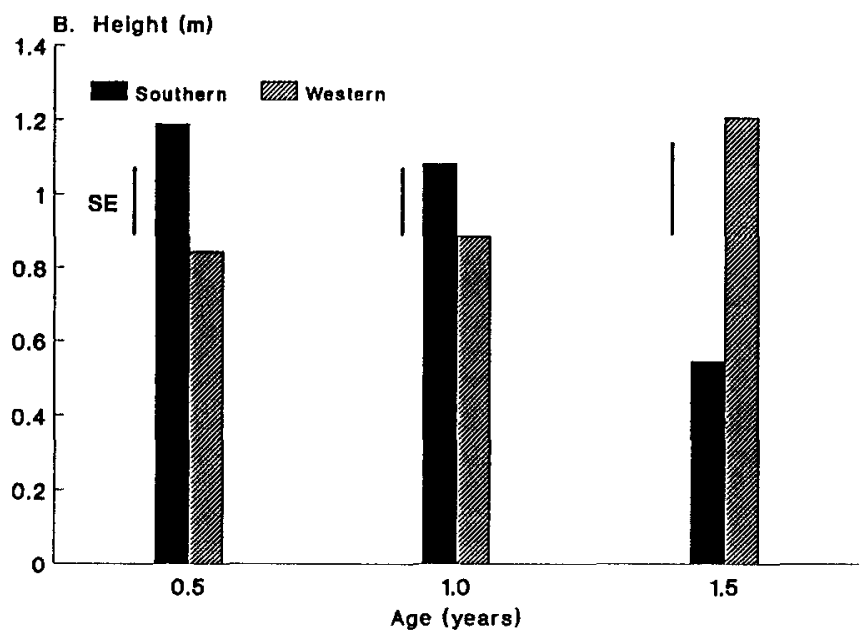

Fig. 2. Basal diameter (a., $\mathrm{cm}$ ) and height (b., m) development of surviving Faidherbia albida origins from southern and Sahelian Africa. ISC, Sadore, Niger. 1988-1990. 


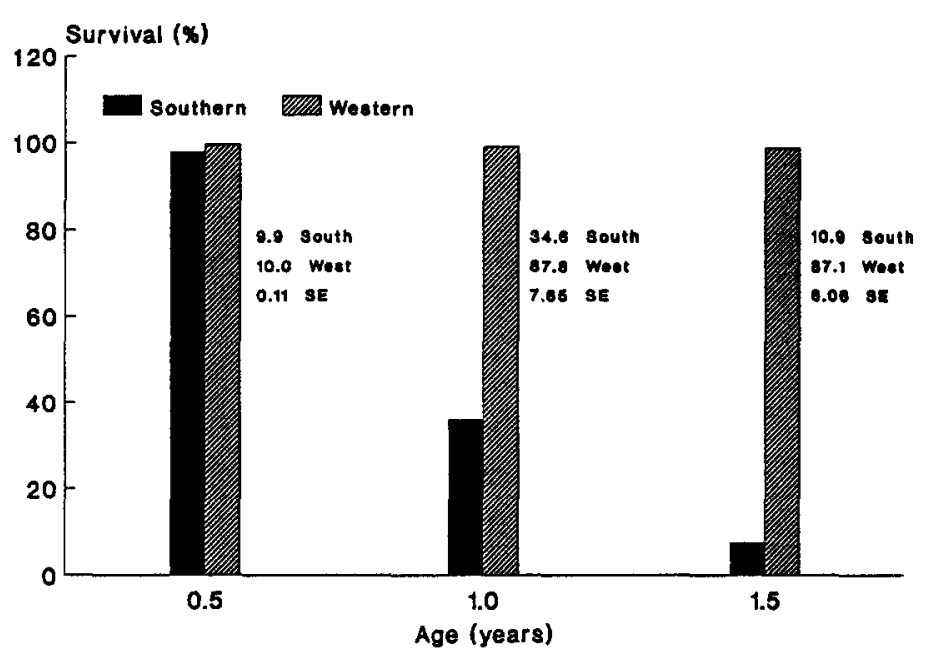

Fig. 3. Survival of 30 southern and western Africa origins of faidherbia albida at Sadore, Niger. Numerical data in columns are corresponding square root $(0.5$ year) or angular $(1.0$ and 1.5 year) transformations.

was about the same in both. Above-ground biomass was similar, reflecting the more bushy and branching growth habit of the Sahelian entries.

Both entries had roughly the same number of primary roots, which rooted straight down the soil profile with little branching or lateral growth to an average depth of $3.2 \mathrm{~m}$. Average root biomass of the Sadore entry was over 3 times that of the Messina, RSA entry. Most of this difference in root biomass occurred in the upper $1.5 \mathrm{~m}$ of the soil profile (Fig. 4a). Further, average root diameter of the Sadore trees was much greater than that of the Messina trees, down to depths of $3 \mathrm{~m}$ (Fig. $4 \mathrm{~b}$ ). No nodules were found on any of the roots at any depth, despite careful and extensive examination of fine roots $(<2 \mathrm{~m})$ along the faces of the excavations.

Table 3. Comparison of root and shoot growth parameters of west and southern African seed origins of Faidherbia albida at 9 months of age $(\mathrm{n}=5)$. ISC, Sadore, Niger.

\begin{tabular}{llll}
\hline Growth parameter & Sadore, Niger & Messina, RSA & $\mathrm{s}_{\mathrm{d}}^{1}$ \\
\hline Basal diameter $(\mathrm{cm})$ & 1.45 & 1.50 & 0.02 \\
Height (m) & 0.78 & 1.16 & 0.09 \\
Shoot biomass (dry, $\mathrm{kg})$ & 0.32 & 0.36 & 0.11 \\
Rooting depth $(\mathrm{m})$ & 3.26 & 3.04 & 0.21 \\
Number of primary roots & 5.2 & 6.4 & 1.2 \\
Root biomass (dry, kg) & 0.40 & 0.12 & 0.09 \\
\hline
\end{tabular}

\footnotetext{
1 Standard error of mean difference.
} 
a)

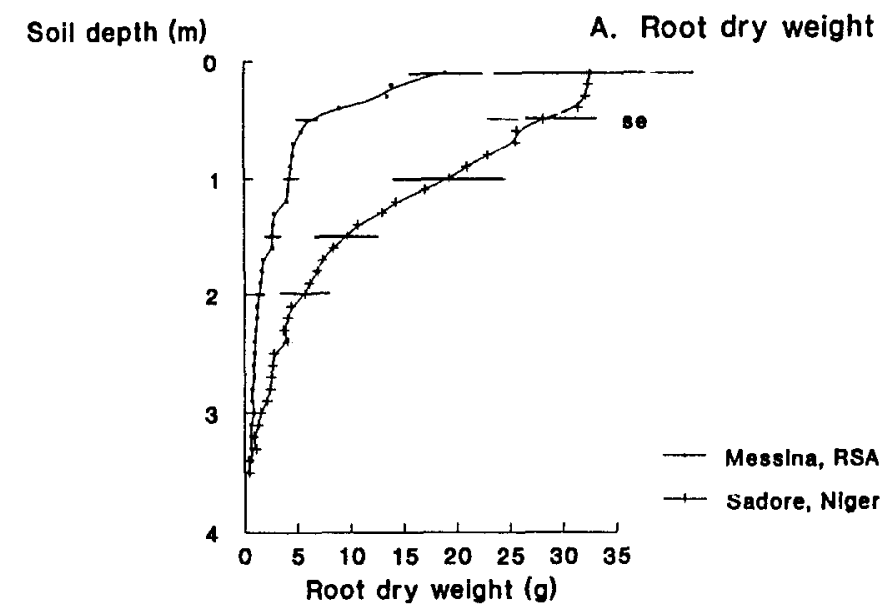

Soil depth $(m)$

B. Root diameter

b)

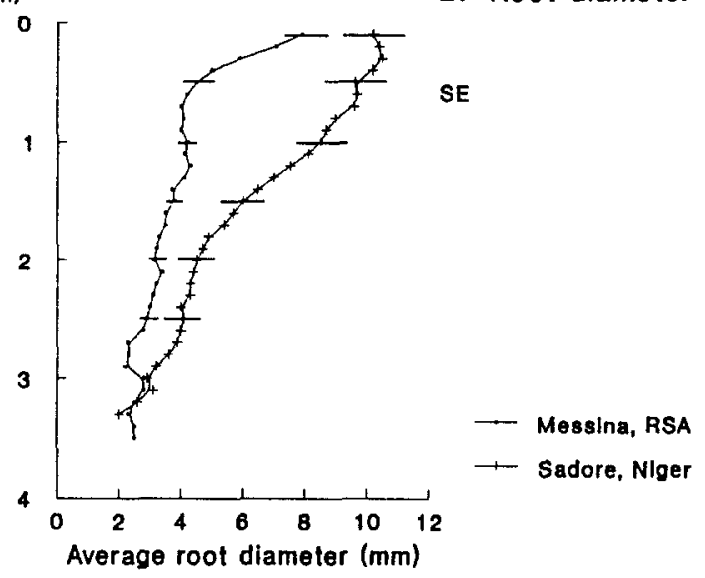

Fig. 4. Distribution of root dry weight (a) and average root diameter (b) with soil depth between Faidherbia albida origins from Sadore, Niger and Messina, RSA at age $=9$ months $(\mathrm{n}=5)$. ISC, Sadore, Niger, 1989.

\section{Discussion}

The introduction of southern African origins of $F$. albida into the Sahel is of limited value. The timing and severity of mortality was similar for all entries from eastern and southern Africa. The root excavations provide strong evidence that this dieback was due principally to inferior root development. 
These results suggest that there are two distinct ecotypes of Faidherbia albida. These are: Ecotype A, the western Africa, plateau type adapted to severe seasonal drought and deep water tables; and Ecotype B, the eastern and southern African, riparian and/or lowland type requiring high water tables to survive drought and seasonal dry periods. The proposed separation of the two ecotypes appears valid in view of the very different environments and concomitant evolutionary pressure from which they emerged. The riparian ecotype would have no need for aggressive, well-formed root systems, a necessity for trees in drier areas. Although F. albida does exist in the Sahel along seasonal and perennial water courses, seed from such stands performs well at ISC when compared with seed of plateau stands ( $R$. Vandenbeldt, unpublished data). Riparian and lowland $F$. albida in West Africa is most likely of Ecotype A.

There are several sizable regional populations not included in this study, i.e., the Angola/Namibia and Sudan/Ethiopia groups. However, the southwest Africa population seems to be of Ecotype B. According to A. Tapson (Director, South African Forestry Research Institute, Pretoria, RSA, personal communication), trees in the zone are invariably riverine. $F$. albida trees along the Kuiseb River in Namibia have died off as the water table has been lowered by pumping for irrigation.

The Sudan/Ethiopian population is, perhaps, of greater importance. Poschen [8] in his description of $F$. albida in the Hararghe highlands of Ethiopia, mentions the species growing both in alluvial plains with access to groundwater tables as well as on other soil types, presumably without access to ground water. He also notes a high degree of heterozygosity in locally selected seed that affects survival of outplanted seedlings. Similarly, Miehe [7], describing the F. albida system in the Jebel Marra highlands in Sudan, distinguishes between the montaine type in that zone which is 'seemingly independent of a perennial groundwater table', and the nearby riverine type in the Wadi Azoum, which would have perennial access to water tables. It appears, therefore, that the two ecotypes grow within close proximity to each other in these areas.

Previous theories regarding the center of origin of $F$. albida include that of Chevalier ([4], cited by Wickens [13]), who believed the species originated in northern Africa and spread south and east. Aubréville ([19, cited and supported by Wickens [13]) on the other hand, argued that the species arose in the east and south near rivers and was spread by man into the west. Neither of these hypotheses, however, were based on data from accessional trials, or derived from examination of rangewide genetic diversity.

The evidence of the present study supports that part of Aubréville's theory proposing the Sudan/Ethiopia region as the center of origin of the species. If this is so, the two ecotypes diverged. Ecotype A moved with pastoral and agricultural activities into western Africa, and Ecotype B followed the Nile system southward into eastern Africa, and from there into southern and southwestern Africa. 
The division of races on the basis of leaflet size and pubescence as described by Brenan [2] is probably not linked to the division by ecotype proposed here. Both of Brenan's races, and a wide range of intermediates, occur throughout western Africa [13], and were represented in this study. Thus, the division of the species on the basis of leaflet size and pubescence appears less important in explaining the center of origin than the gross physiological differences in rooting behavior and photosynthate partitioning between the geographical and ecological types proposed here.

\section{Conclusions}

It is important to include seedlots from both ecotypes in adaptive trials outside its native range. Use of $F$. albida seed from southern and eastern Africa is not indicated where there is a possibility of severe seasonal drought and/or deep water tables. An example of this are recent studies in India, wherein seedlots from Kenya (Ecotype B) have performed exceptionally well over a five year period in peninsular India on heavy Alfisols (CK Ong, ICRISAT, Hyderabad, India, personal communication), but have failed in the more arid Rajasthan on sandier soils (NG Hegde, Bharatiya Agro Industries Foundation, Pune, India, personal communication).

It would be of considerable interest to see if Ecotype B could be introduced in riverine habitats and rice-growing areas of the Sahel, and in the more humid Sudanian zone of western Africa. Similarly, use of Ecotype A in non-riparian areas of southern and eastern Africa may prove to be of benefit.

Future genetic studies of the species and collection efforts should bear in mind the difference between the ecotypes proposed here. If subsequent study shows that the center of diversity of the species is indeed the Sudan/ Ethiopia region, then careful collection and testing of populations from this zone will be crucial to genetic improvement of $F$. albida.

\section{Acknowledgements}

The author would like to thank John Heermans, George Taylor and Phil Serafini for reading early drafts of this paper and providing useful and constructive comments.

\section{References}

1. Aubréville A (1950) Flore forestière soudano-guinéenne. A.O.F., Cameroun, A.E.F. Société d'éditions géographiques, maritimes et coloniales, Paris

2. Brenan JPM (1983) Manual on taxonomy of Acacia species. Food and Agricultural Organization of the United Nations, Rome 
3. Charreau C and Vidal P (1965) Influence de l'Acacia albida Del. sur le sol, nutrition minerale et rendements des mils Pennisetum au Sénégal. Agronomie Tropicale. XX $(6-7): 600-625$

4. Chevalier A (1928) Révision des Acacias du Nord, d l'Ouest et du centre Africain. IV, Le bois des Acacias. Rev. Bot. Appl. 8: 646-650

5. Dancette C and Poulain JF (1969) Influence of Acacia albida on pedoclimatic factors and crop yields. African Soils 14(1-2): 143-184

6. CTFT (1988) Faidherbia Albida (Del.) A. Chev. (Synonyme: Acacia albida Del.). Monographie. Centre Technique Forestier Tropical. Nogent-sur-Marne, Cedex, France

7. Miehe S (1986) Acacia albida and other multipurpose trees on the fur farmlands in the Jebel Marra highlands, Western Darfur, Sudan. Agroforestry Systems 4: 89-119

8. Poschen P (1986) An evaluation of the Acacia albida-based agroforestry practices in the Hararghe highlands of Eastern Ethiopia. Agroforestry Systems 4: 129-143

9. SAS (1985) SAS Procedures Guide for Personal Computers. SAS Institute, Inc., North Carolina, USA

10. Sivakumar MVK (1986) Climate of Niamey. Progress report \#1. ICRISAT Sahelian Center, Niamey, Niger

11. Vassal, J. et al. (1977) Distribution maps of African Acacia species. Groupe international pour l'étude des Mimosoideae no. 5, $31 \mathrm{p}$

12. West LT, Wilding LP, Landeck JK and Calhoun FG (1984) Soil Survey of the ICRISAT Sahelian Center, Niger, West Africa. Soil and Crop Sciences Department/ TropSoils. Texas A\&M University, College Station, Texas, USA

13. Wickens GE (1969) A study of Acacia albida Del. (Mimosoideae). Kew Bulletin 23(2): $181-202$ 